\title{
Resensie-artikel
}

\section{Anton van Niekerk - Rasionaliteit en relativisme. Op soek na 'n rasionaliteitsmodel vir die menswetenskappe. 1992. Pretoria: RGN.}

\author{
Pieter van Veuren \\ Departement Filosofie \\ Randse Afrikaanse Universiteit \\ JOHANNESBURG
}

\begin{abstract}
This review article places Van Niekerk's book in the context of the current debate on rationality and relativism. The most important challenge which emerges from this debate is to develop a conception of rationality which neither reverts to an a-historical foundationalism nor succumbs to the temptation of relativism. Van Niekerk responds to this challenge by developing a hermeneutical model of rationality for the human sciences. My discussion of Van Niekerk's book highlights his critique of relativism and his efforts to reconcile rationality and historicity. In evaluating his arguments for this reconciliation, I come to the conclusion that his efforts are beset by unresolved tensions.
\end{abstract}

\section{Inleiding}

Het die antieke Grieke reeds vele belangrike filosofiese probleme vir ons voorgedink? Anton van Niekerk se antwoord op hierdie vraag is: in 'n sekere sin, ja! Volgens die skrywer van Rasionaliteit en Relativisme (voortaan $R \& R$, gesiteer met bladsynommers) het die projek van Westerse rasionaliteit sy oorsprong in die Griekse Verligting se onderskeid tussen doksa (mening) en episteme (wete/kennis)(iii, 4). Sedert dié tyd is 'rasioneel' 'n kwalifikasie van kennisaansprake, en hou dit verband met 'n sekere soort verantwoording van sulke aansprake, naamlik deur steekhoudende intersubjektief-geldende redes (3). 'Redes', 'redelikheid' en oopheid vir bevraagtekening en debat, asook 'objektiwiteit' in die sin van intersubjektiewe geldigheid onderskei die redelikheid van die Griekse filosofie en wetenskap van die Griekse mite wat sy oortuigingskrag ontleen aan die gesag van tradisie, priesters en goddelike magte (3). 
Die 'lig' van die redelikheid is egter nie onkorrupteerbaar nie: sedert die Griekse sofis Protagoras word rasionaliteit vergesel deur die skadu van relativisme. Volgens Protagoras is kennis en waarheid relatief tot die individuele persoon wat die oortuiging huldig. 'n Stelling is waar (vir my) as dit vir $m y$ lyk of dit waar is; dit is vals as dit vir $m y$ lyk of dit vals is (20). My mening oor enige saak is dus gelykwaardig aan die mening van enige ander persoon se mening wat meen dat sy mening waar is, solank ek ook oortuig is dat my mening waar is. Op dié manier bestaan daar nie valse menings nie! (19). Dit is sonder meer duidelik dat 'redes', bevraagtekening en debat, asook intersubjektief-geldige kriteria en reëls in hierdie soort relativisme geen rol kan speel nie. Om 'n ander tot jou siening oor te haal, moet jy hom of haar mislei met retoriese middele: beroepe op algemene standaarde en logiese reëls het geen sin nie.

$R \& R$ het nie as doel om ' $\mathrm{n}$ historiese oorsig oor die probleem van rasionaliteit en relativisme vanaf die Grieke tot vandag te gee nie. Die benaderingswyse is toegespits op hierdie problematiek in die wetenskapsfilosofie van die afgelope 60 jaar. Die problematiek van rasionaliteit en relativisme by die Grieke het egter ' $n$ oorsigtelikheid en 'n eenvoud wat 'n mens kan help om jou te oriënteer vir die ingewikkeldhede en onoorsigtelikheid van die huidige debat wat bepaal word deur concerns wat tipies 'modem' is: die moderne natuurwetenskappe en menswetenskappe met hulle gedifferensieerde subdissiplines, en die tipies twintigsteeeuse 'historiese bewussyn'.

'n Vroee fase van die debat oor rasionaliteit en relativisme in die twintigste eeu kan gevind word in werke van onder andere Wilhelm Dilthey, Wilhelm Windelband en Heinrich Rickert. Die jongste fase van die debat is beslissend beinvloed deur Thomas Kuhn (1962) se boek oor rewolusies in die natuurwetenskap en Hans-Georg Gadamer (1960) se Wahrheit und Methode. Hierdie twee werke het 'n beslissende bydrae tot die transendering van die positivistiese wetenskapsbeeld gelewer. Gevolglik vind die nuutste fase van die debat plaas in die konteks van ' $n$ post-positivistiese wetenskapsbeeld wat vir 'n belangrike deel deur Kuhn en Gadamer geskep is. Binne hierdie konteks word die debat oor rasionaliteit en relativisme deurkruis deur onder andere die debat oor moderniteit en post-moderniteit (o.a. Schrag, 1989) en die debat oor 'wetenskaplike realisme' (o.a. Bachelard, 1985)

Miskien is die dringendste wetenskapsteoretiese opgawe wat die debat laat uitkristalliseer die noodsaak om 'n nuwe rasionaliteitsbegrip te onwikkel. So 'n 'nuwe' rasionaliteitsbegrip sal nóg op 'n universele, ahistoriese fundering aanspraak maak, nóg swig voor die verleiding van relativisme. Schrag (1989) Matthews (1988) en Bernstein (1983) werk almal in die rigting van so 'n 'nuwe' rasionaliteitsbegrip. Dit is ook die opgawe wat Van Niekerk vir homself stel in sy boek. 
Vir die doeleindes van hierdie resensie-artikel sal ek my bespreking van $R \& R$ toespits op wat myns insiens Van Niekerk se belangrikste bydrae tot die debat oor rasionaliteit en relativisme is, naamlik die manier waarop hy die wesenlike probleme van die debat toespits, en die hermeneutiese rasionaliteitsmodel wat hy vir die menswetenskappe ontwikkel. Ek sal in die bespreking wat volg 'n oorsig gee van die argumentatiewe samehang van die boek en die begripsverheldering wat deur die outeur bereik word. Daarna sal ek by wyse van 'n kritiese evaluasie terugkom op die aanduidings wat die skrywer gee vir die ontwerp van 'n 'hermeneutiese' rasionaliteitsmodel vir die menswetenskappe.

\section{Hooflyn van die argumentasie}

Die sentrale vraag wat die ondersoek van $R \& R$ lei, is dié na 'n rasionaliteitsmodel vir die menswetenskappe. Die skrywer stel hierdie vraagstuk emfaties aan die orde téén die neiging wat daar in die filosofie van die menswetenskappe, maar ook in die filosofie van die natuurwetenskappe is - die neiging naamlik om af te sien van die idee van rasionaliteit (soos hierbo omskryf) ten gunste van die idee van ' $n$ 'lokale' of 'kultuurgebonde' rasionaliteit, wat sinoniem is met relativisme.

Die boek is verdeel in twee afdelings: die eerste handel oor die 'verleiding' van relativisme in die hedendaagse filosofiese wetenskapsbeeld. In hierdie afdeling word agtereenvolgens die ontwikkelinge in die mens- en natuurwetenskappe op so 'n manier gerekonstrueer dat die onvermydelikheid van 'n wetenskapsfilosofiese relativisme belig word. Hierdie werkwyse stel die skrywer in staat om die argument vir relativisme op ' $n$ oortuigende manier te stel. Die argumente vir relativisme word verder op die spits gedryf in 'n bespreking van die "Strong Programme" van die Edinburgh-skool en die neo-pragmatisme van Richard Rorty.

Die tweede afdeling bring ' $n$ wending in die argumentasie: terwyl die 'verleiding' van relativisme, en die pro-relativisme-standpunt in die eerste deel uitgewerk is, word in die tweede deel die "verleiding' ontluister ("relativisme gerelativeer") en word ' $n$ begin gemaak met die rehabilitasie van die idee van rasionaliteit, via 'n bespreking van twee verruimde konsepsies van rasionaliteit (Eksistensiële Fenomenologie en Habermas se teorie van kommunikatiewe rasionaliteit). Die boek se argumentasie loop ten slotte uit op 'n skets van 'n nie-relativistiese, hermeneutiese redebegrip vir die menswetenskappe.

\section{Rasionaliteit en relativisme}

Dít is dan in breë trekke die argumentatiewe progressie of 'verhaal' in die boek. Die leser kry ook gaandeweg 'n verdiepte insig in die kompleksiteit van die kernbegrippe rasionaliteit en relativisme. Hierdie twee begrippe kan eintlik nie geheel los van mekaar bespreek word nie want relativisme in sake van rasionaliteit 
Resensie-artikel: Rasionaliteit en relativisme (Van Niekerk)

veronderstel ' $n$ reeds bestaande nie-relativistiese siening van rasionaliteit. Die rasionaliteit waaroor dit in hierdie boek gaan, is dié wat in die wetenskap ter sake is: dit is verbonde aan die kriteria waaraan wetenskaplike kennisaansprake gemeet word en die prosedures waardeur sulke aansprake begrond of getoets word $(6,210)$. Die tradisionele nie-relativistiese siening is dat bogenoemde kriteria en prosedurele reëls sowel universeel geldig as ahistories, tydloos geldig is (118).

Van Niekerk het waarskynlik gelyk as hy die twintigste eeu teken as die eeu van relativisme: versnelde kultuurontwikkeling gaan gepaard met die ondermyning van alle aansprake op standhoudende sekerhede en universeel geldende norme en kriteria (iii).

Dit is verhelderend om hierdie proses van die twintigste eeu in die breë konteks te plaas wat deur Nietzsche ${ }^{1}$ geskets word in Götzen-Dämmerung en die opskrif het 'Hoe die ware wêreld ten slotte ' $n$ fabel geword het: geskiedenis van 'n fout' (Nietzsche, 1966(2):363).

1. Die ware wêreld, bereikbaar vir die wyse, vroom, deugsame mense ... (Oudste vorm van die Idee, relatief wys, eenvoudig, oortuigend ...). [Plato se ideë-wêreld].

2. Die ware wêreld, vir nou onbereikbaar maar beloof aan die wyse, vroom, deugsame mense ('vir die sondaars wat boete doen'). [Die Middeleeus-Christelike gedagte van 'n 'hemel' waar God woon.]

3. Die ware wêreld, onbereikbaar, onbewysbaar, onbeloofbaar, maar as gedinkte wêreld 'n troos, 'n verpligting, 'n imperatief. (Die ou son, maar gesien deur mis en skepsis heen, die Idee het subliem geword ...). [Die Kantiaanse 'wêreldlose' formele wêreld van die regulatiewe rede-ideë van God, die hoogste goed, ensovoorts.]

4. Die ware wêreld - onbereikbaar? In ieder geval onbereik. En as onbereik ook onbekend. Gevolglik ook nie troostend, verlossend, verpligtend nie ... [Positivistiese anti-metafisika.]

5. Die 'ware wêreld' - 'n idee wat vir niks meer deug nie, nie eers meer verpligtend is nie - 'n nutteloosheid, 'n oorbodige idee, gevolglik 'n weerlegde idee: laat ons dit afskaf?

6. Die ware wêreld is deur ons afgeskaf: watter wêreld bly oor? Die skynbare miskien? ... Maar nee! Met die ware wêreld het ons ook die skynbare wêreld afgeskaf! (... hoogtepunt van die mensheid; INCIPIT ZARATHUSTRA)

$1 \quad$ Ek gee hier 'n vrye vertaling uit die Duits; frases tussen vicrkantige hakies is deur my bygevoeg om die strekking van Nietzsche se stellings te verduidelik. 
Hierdie ses punte stel myns insiens die parameters van die verval (en die pogings tot transendering) van die Westerse metafisika as begronding van universeelgeldige en ahistoriese kriteria en reëls. Dat die transendering daarvan nog nie eenduidig geluk het nie, blyk uit die talle transenderingseksperimente: Nietzsche se kriptiese "incipit Zarathustra", Emst Bloch se kreatiewe materie, Wittgenstein se taalspele, Rorty se "conversation" en Derrida se "différance", om 'n paar te noem. Dit blyk ook uit die terugkeer na vroeëre stasies van die historiese weg (byvoorbeeld "Sein" by die latere Heidegger, die empiriese datum by die Logiese Empirisme).

Afskaffing van en pogings tot transendering van die metafisika loop uit op verskillende relativismes (sosiaal, eties, juridies) waarvan Van Niekerk dié bespreek wat belangrik is vir die wetenskapsfilosofie. Vir Van Niekerk gaan dit primêr oor relativisme as "inkommensurabilisme, dit is die siening dat, in die lig van alternatiewe teorieë, paradigmas, navorsingsprojekte, ensovoorts, navorsers nie in staat is om in hulle eie terme ' $n$ adekwate beeld te vorm van ' $n$ alternatief se konsepsies nie" (21). Daar is ook geen neutrale grond waarop 'n keuse tussen twee of meer alternatiewe met betrekking tot waarheid of rasionele regverdiging gemaak kan word nie. Van Niekerk noem hierdie siening ook "epistemologiese relativisme" (21). Ietwat breër geformuleer, kom hierdie siening daarop neer dat daar geen vaste en transkulturele (universele) standaarde of metodes is vir die bepaling van die rasionele status van kennisaansprake en handelinge nie. Dit is die standpunt van onder andere Winch en die "Strong Programme" van Bames en Bloor. Wat hierbo gesê is oor die inkommensurabiliteit van teorieê en paradigmas, geld ook vir kulture: navorsers is nie in staat om in hulle eie terme ' $n$ beeld te vorm van ' $n$ eksotiese kultuur se verhale en praktyke nie. ' $n$ Neutrale, algemene taal ontbreek. Positief geformuleer: kriteria vir uitsprake en handelinge is op ' $n$ radikale manier 'lokaal', konteksafhanklik of groepsbepaald en kontingent, dit wil sê hulle kan ook anders gewees het as wat hulle is. Hierdie uitgangspunt impliseer dat daar ' $n$ onreduseerbare pluraliteit van kriteria bestaan. Gevolglik is daar in Rorty (1985:6) se woorde:

... nothing to be said about either truth or rationality apart from descriptions of the familiar justification which a given society - ours - uses in one or other area of inquiry.

Volgens Van Niekerk se tekening van die menswetenskappe is juis die teorie van hierdie wetenskappe op ' $n$ besondere manier vatbaar vir 'lokalisme' in sake van rasionaliteit weens die besondere aard van die objekte van ondersoek en die ondersoekproses self (31). Die hermeneutiese sirkelstruktuur van menswetenskaplike navorsing (31) maak ons verstaan van die objekte van ondersoek (aksies, geskrewe tekste, kunswerke, gedragspatrone, samelewingstrukture, praktyke, ensovoorts) onontwykbaar 'gelokaliseerd': ons begin ons verstaansproses altyd van- 
uit 'n onophefbare 'voor-verstaan', 'n historiese en linguistiese verstaanskader wat ons as enkelinge met ons tydgenote deel (30). Nie alleen die ondersoekproses het 'n lokale karakter nie, maar ook die objekte van ondersoek: hulle het 'n onophefbare linguïstiese karakter. Hulle is lokale, konteksgebonde interpretasies waarvan ons her-interpretasies gee (31) - her-interpretasies wat skynbaar ook nie ontsnap aan 'lokaliteit' of konteks nie.

\section{Die 'verleiding' van relativisme}

Die voorgaande oorweginge verhelder die affiniteit wat die metateoric van die menswetenskappe dikwels vir relativisme het, en maak dit aanneemlik dat daar sprake kan wees van "resignasie voor die relativismeverleiding" in beskouinge oor rasionaliteit in die menswetenskappe (32). Wat myns insiens egter nie in $R \& R$ voldoende belig word nie, is die inhoud van die verleiding van relativisme in die hedendaagse filosofiese wetenskapsbeeld. (Dié gekursiveerde frase is die opskrif vir Afdeling A van die boek.) Die werklike inhoud van die verleiding regverdig nie terme wat Van Niekerk graag gebruik om na relativistiese beskouings te verwys nie, byvoorbeeld "relativistiese uitvlug" (33) en "verskoning vir relativisme" $(32,38)$. Die eintlike inhoud van die verleiding word skrams aangeraak in Feyerabend se rehabilitasie van tradisie, gesag, voorkeure, propaganda, ideologie, ensovoorts, deur die gees van relativisme:

These 'deviations', these 'errors' are preconditions of progress. They permit knowledge to survive the complex and difficult world which we inhabit, they permit us to remain free and happy agents (Feyerabend, 1975:179-80).

Wilhelm Dilthey se formulering van dieselfde gedagtegang 2 in terme van die insig van die 'historiese bewussyn' in die relativiteit van wêreldbeskouings, bring die kemsaak waarom dit hier gaan eksplisiet uit: 'Die historiese bewussyn verbreek die laaste kettings wat filosofie en die natuurwetenskappe nie kon verbreek nie. Die mens is nou geheel en al bevry' (Dilthey, 1968:255). Die inhoud van die 'verleiding' van relativisme is onbegrensde ruimte vir vrye self-skepping. Nietzsche verwys hierna in punt 6 van sy 'Geskiedenis van 'n fout'. Die relativisme wat dié onbegrensde vryheid onderlê, het egter kostes wat vir Van Niekerk onaanvaarbaar is; daarom onderwerp hy relativistiese teorieë oor rasionaliteit aan 'n indringende kritiek (125-165). 


\section{Relativisme weerlê}

Ruimte ontbreek hier om Van Niekerk se gesofistikeerde argumente teen die relativisme van Kuhn, Feyerabend, Barnes en Bloor, Winch, Rorty en ander in detail na te gaan en te evalueer. Daarom word volstaan met aanduidings van die hoofpunte van sy argumentasie teen relativisme.

Eerstens: relativisme is 'n inkoherente standpunt, dit wil sê dit is selfondermynend. As relativisme reg is, word die idee dat enigiets reg kan wees, na sy wese ondermyn (130). Ook, as enige oortuiging so goed is soos enige ander een, moet die relativis erken dat ' $n$ ander oortuiging, wat meen dat die relativistiese standpunt verkeerd is, ook goed (waar) is (27). Die meer beperkte relativisme-tese is ook inkoherent: om te sê dat relativisme slegs in 'n relatiewe sin (dit wil sê relatief tot ' $n$ individu of gemeenskap) waar is, impliseer dat relativisme na eie erkenning nie beter as enige van die alternatiewe vir relativisme is nie.

Hierdie kemargumente wat die koherensie van die relativistiese posisie bevraagteken, word deur Van Niekerk gewend teen Feyerabend, Barnes en Bloor, en Rorty wat hulle op verskillende maniere teen bogenoemde anti-relativistiese argumente probeer afskerm, maar volgens Van Niekerk nie daarin slaag nie (128133).

Van Niekerk gee besondere aandag aan die relativisme-tese in die vorm van Kuhniaanse "inkommensurabiliteit" (21). Volgens Kuhn se beskouing is kompeterende paradigmas nie vergelykbaar nie omdat hulle nie alleen teorieë onderlê nie, maar ook die konflikterende kriteria waarvolgens teorieë beoordeel word. Rasionaliteit is 'n begrip wat vir Kuhn slegs intra-paradigmaties betekenis het (135). Daar bestaan dus nie gedeelde of inter-paradigmatiese kriteria vir rasionaliteit nie. Hierdie stelling word egter nie deur Kuhn aanneemlik gemaak nie (136). Deurdat Kuhn die idee van wetenskaplike rasionaliteit relativeer tot ' $n$ mode van historiese gemeenskappe, ondermyn hy sy eie projek, naamlik om met behoud van konseptuele helderheid en koherensie 'n "geskiedenis van die wetenskap" te skryf (140).

Aangesien morele en epistemologiese relativisme volgens Van Niekerk onverbreeklik gekoppel is, maak ' $n$ kritiek van die etiese en politieke konsekwensies van relativisme deel uit van sy afwysing daarvan. Sy beswaar teen relativiste is dat hulle nie die etiese gevolge van hulle standpunte emstig genoeg opneem nie (165). ' $n$ Relativis het naamlik geen oortuigende gronde om reg van verkeerd en goed van kwaad te onderskei nie (165). Betuigings deur relativiste van 'solidariteit' met demokratiese en liberale waardes van die Westerse tradisie, is vir Van Niekerk nie baie oortuigend nie, want as hulle reg is in hul relativisme kan hulle nie reg wees oor die waarde van hierdie waardes nie: hulle standpunt ondermyn die idee dat enigiets meer reg kan wees as iets anders (166). Die rela- 
Resensie-artikel: Rasionaliteit en relativisme (lan Niekerk)

tivistiese standpunt bied gevolglik ook nie grond vir 'n kritick van die politiek en samelewing nie (byvoorbeeld van Nazisme en apartheid). Vandaar dan ook die affiniteit van relativisme vir 'n neo-konserwatistiese politiek (168).

\section{Alternatiewe weë}

Tot dusver het my bespreking van $R \& R$ getrag om die hooflyne te trek van Van Niekerk se toespitsing van die problematiek van relativisme in die kontemporêre wetenskapsfilosofie, en van sy kritiek daarop. In die laaste afdeling van hierdie bespreking sal ek die hooftrekke van Van Niekerk se alternatief vir relativisme krities-evaluerend skets. As ek praat van Van Niekerk se 'alternatief' vir relativisme laat ek dit wat hy bied miskien meer pretensieus klink as wat hy self bedoel het dit moet wees. Hy gee nie soseer 'n alternatief' nie as wat hy weë verken om 'n nie-relativistiese rasionaliteitsmodel vir die menswetenskappe te omlyn. Die subtitel van die boek is "Op soek na 'n rasionaliteitsmodel vir die menswetenskappe" (my kursivering). In die verloop van sy argumentasie kwalifiseer hy hierdie projek: dit is nie soseer sy doel om 'n enkele rasionaliteitsmodel vir die menswetenskappe te verken nie, maar om 'n stel gesigspunte te gee wat met die nodige dissiplinêre toespitsing in alle moontlike rasionaliteitsmodelle van die menswetenskappe verreken behoort te word (202).

Die alternatiewe weë wat Van Niekerk verken in sy soeke na 'n rasionaliteitsmodel vir die menswetenskappe stuur weg van tradisionele nie- of anti-relativistiese beskouings wat volgens Van Niekerk herlei kan word tot twee opsies. Die eerste is die "rasionalistiese" of "objektivistiese" opsie wat sy hoogtepunt in Hegel se filosofie bereik: alle relatiwiteit is opgehef in die absolute idee waarin werklikheid en insig in die werklikheid saamval, en so 'n absolute vaste punt daarstel. Die tweede opsie is die empiristiese opsie: die vaste ankerpunt vir ons denke is die sintuiglike ervaringstuk, 'n brute, vir sigselfsprekende en ondubbelsinnige "datum" (34).

Hierdie twee opsies kan in Nietzsche se 'Geskiedenis van 'n fout' verbind word aan punt 1 en punt 4: Hegel rehabiliteer die Platoniese metafisika minus Plato se dualisme tussen ware ideëwêreld en verskynselewêreld, terwyl die term positivisme se betekenis breed genoeg is om August Comte en die latere Logiese Empirisme te omvat.

Hoe staan Van Niekerk teenoor dié twee opsies? Hy is van mening dat die alternatiewe weë wat hy verken in sy soeke na 'n rasionaliteitsmodel in die menswetenskappe, hierdie opsies agterlaat sonder om in relativisme uit te loop. In terme van Nietzsche se skematiese 'Geskiedenis van 'n fout', volg Van Niekerk nie Nietzsche (en Rorty, Derrida en ander) deur fases 5 en 6 nie, juis omdat hulle op relativisme uitloop. 
Tegelykertyd is insig in die konteks-afhanklikheid van rasionaliteit vir Van Niekerk 'n posisie waaragter nie meer teruggeval kan word nie; hy wil geen objektivis of foundationalist in ' $\mathrm{n}$ ahistoriese sin wees nie (145). Hy aanvaar dat

... die idee dat rasionaliteit verwys na 'n tydloos geldige verantwoordingsmeganisme vir kennisaansprake, en wat sigself bedien van kriteria vir die beoordeling van kennisaansprake wat insgelyks universeel en tydloos vir alle groepe, kulture en omstandighede geld, 'n grootliks agterhaalde opvatting is (118)

Wetenskap en die rasionaliteit in terme waarvan die wetenskap fuksioneer, is nie soseer "vondste" nie as "maaksels" van 'n bepaalde kultuur (118). Konsekwentgewys aanvaar Van Niekerk dan ook dat "Westerse rasionaliteit" nie 'n tydlose en universeel voorkomende, algemeen menslike verskynsel is nie, maar dat dit wel die produk van historiese ontwikkelinge is. Dit is naamlik 'n produk van die Griekse Aufklärung, en ondergaan sedert daardie epogmakende moment in ons geskiedenis ook verdere ontwikkelinge (145).

Dit is duidelik dat Van Niekerk met hierdie standpuntinname nie intellektueel tenugdeins vir die belangrikste insigte van die kontemporêre filosofie nie: die eindigheid van die mens; die 'historiese bewussyn'; die onvoltooidheid en onvoltooibaarheid van die projek van die wetenskap. Dit is egter ook duidelik dat hy besig is met 'n soort intellektuele brinkmanship want sy standpuntinname bevat al die elemente wat tradisioneel lei tot relativistiese konsekwensies in sake van rasionaliteit. Vermyding van hierdie konsekwensies is by Van Niekerk ' $n$ kwessie van nuansering (kyk byvoorbeeld 280). Dit maak sy standpuntinname kompleks, maar tegelyk spanningsvol, en daarom ook interessant.

Dit is nie sonder meer duidelik dat "Westerse rasionaliteit" (145) enersyds ' $n$ "maaksel" is, nie ' $n$ "algemeen menslike verskynsel" is nie, maar ' $n$ historiese tradisie is, en dat andersyds wetenskaplike rasionaliteit nie ' $n$ groepsverskynsel is nie (nie 'lokaal' is nie). Die versoenbaarheid van rasionaliteit en historisiteit is dus iets wat beredeneer moet word (123).

Uit Van Niekerk se uitsprake oor die historisiteit van "Westerse rasionaliteit" wat hierbo gesiteer is, lyk dit of hy probleme kan hê met die algemeenheid of universaliteit van wetenskaplike kennis en kriteria. Wetenskap is, volgens Van Niekerk, per definisie nie 'lokaal' nie

Die wetenskap het, by wyse van spreke, geen vaderland nie. As dit vir sy geldigheidsaansprake gebonde sou wees aan net maar die instemming van die inwoners van ' $n$ vaderland, resp. die lede van ' $n$ bepaalde groep, sou dit sy identiteit prysgee (143). 
Hierdie punt is vir Van Niekerk belangrik, want as wetenskap afhanklik gestel word van groepspesifieke norme, word dit verideologiseer en verloor dit die ideologie-kritiese invloed wat dit dikwels reeds in die geskiedenis van Westerse samelewings uitgeoefen het (144).

Die universele geldigheid van wetenskaplike kennis is vir Van Niekerk nie soseer 'n eienskap van wetenskaplike kennis as sodanig nie (dit is steeds voorlopig en onvoltooid); wetenskaplike kennisaansprake het slegs 'n strewe na universele geldigheid $(6,143)$; dit wil sê: wetenskaplike kennisaansprake word geformuleer met die intensie dat hulle teenoor prinsipieel verwisselbare mede-subjekte verantwoordbaar moet wees (208). Hierdie uitspraak beteken egter nie dat daar 'n algemene evidensie is wat letterlik almal oortuig van die waarheid van wetenskaplike uitsprake nie; dit gaan om "subjekte wat oor die nodige agtergrondkennis beskik" (208); dit wil sê: subjekte wat die spelreëls van wetenskaplike verantwoording ken en gehoorsaam. Hiermee word die saak myns insiens problematies, want dié subjekte vorm 'n bepaalde/spesifieke groep.

Rasionaliteit en historisiteit word myns insiens nie nader aan 'n versoening gebring deur bogenoemde groep bloot groter te maak nie, deur byvoorbeeld te wys op die gelykskakelende en universaliserende uitwerking van wetenskapsbeoefening as kultuuraktiwiteit (142).

Van Niekerk wys op die "grensoorskrydende" kenmerke van wetenskapsbeoefening (144) en van die verwetenskapliking van die tegniek: dit bevorder kommunikasie oor grense heen, standaardiseer norme en universaliseer pligte. Hierdeur ontstaan daar 'n groeiende globale konsensus oor kriteria vir rasionaliteit, moraliteit en waarheid (144). Dit lyk of Van Niekerk hier 'n empiriese argument voer teen Kuhn, Feyerabend en ander se aandrang op inkommensurabiliteit tussen wetenskaplike paradigmas en kulturele leefwêrelde (146).

Dit lyk of die probleem van brûe wat kultuurverskille kan oorkom, inkommensurabiliteit van paradignas en teorieë, intersubjektiewe kriteria en waardes, en die probleem van historiese veelheid, vir Van Niekerk opgelos word deur die triomftog van Westerse kapitalisme, wetenskap en tegnologie wat 'n globale gelykskakelingsproses aandryf (143). 'n Vraag wat hierby opkom, is of Van Niekerk nie met hierdie gedagtegang 'n variant van die 'etnosentrisme-tese' verdedig nie? Waarom moet die "planetêre" uitbreiding van Westerse wetenskap en tegniek voorrang verkry bó ander alternatiewe? Op hierdie vraag antwoord van Niekerk: dit lyk of ons (en mense van ander kulture) beter oor die weg kan kom met, eerder as sonder, Westerse wetenskap en tegniek (144).

Van Niekerk distansieer hom egter van die etnosentrisme-tese: dit is vir hom nie 'n houdbare alternatief vir sosiale relativisme nie, want konsensus in terme van vertaling (van tale, oortuigings, ensovoorts) is eerder die reël as die uitsondering 
(148). Hierdie uitgangspunt verraai iets omtrent 'n konseptuele gemeenskaplikheid wat nie verreken word deur die standpunt van sosiale relativisme en die etnosentrisme-tese nie (148). In Charles Taylor se terme geformuleer: wisselwerkende kommunikasie tussen samelewings wat vir mekaar 'vreemd' is, kan 'n onderlinge verstaan in ' $n$ taal van deursigtige kontras (a language of perspicuous contrast) tot gevolg hê. Anders as wat Van Niekerk se uitsprake oor 'kulturele gelykskakeling' suggereer, is daar tog sprake van 'n beïnvloedingsproses wat wedersyds tussen Westerse en 'vreemde' kulture verloop, en wat tot gevolg kan hê dat ons (Westerlinge) ons self-verstaan en probleemoplossingstrategieë hersien en verander (155).

Daar bly myns insiens egter nog 'n probleem in Van Niekerk se argumentasie: 'n 'taal van deursigtige kontras' veronderstel bepaalde human constants, byvoorbeeld die "praktyk van redenering" en "sensitiwiteit vir logiese afleiding" (154). Hoe is dié constants, wat basiese voorwaardes vir rasionaliteit vorm, versoenbaar met historisiteit?

\subsection{Rasionaliteit as kriteria}

Hierdie problematiek kom weer 'n keer eksplisiet aan die orde wanneer Van Niekerk kriteria vir wetenskaplike rasionaliteit bespreek. Voorop staan die bevestiging van die historisiteit van sulke kriteria: die

... reëls vir logiese argumentasie en deduktiewe afleiding, die verwoording van basiese waarnemings, die evaluering van hipoteses in terme van hoe suksesvol hulle is vir die oplossing van duidelik omskrewe probleme - ... hierdie dinge is ... nie 'tydloos waar' of 'onveranderlik/onhersienbaar geldig' nie (212).

Hieruit volg egter vir Van Niekerk nie die relativistiese konsekwensie dat 'daarom' oortuigings wat berus op bygeloof of sterrewiggelary of rassistiese veroordeel "net so goed" is nie (212). Hoe vermy hy die relativistiese konsekwensie? Deur twee beroepe: eerstens deur ' $n$ beroep op ' $n$ realistiese ontologie: dit is 'n "oer-intuïsie" van die Griekse Aufklärung en die "grondoortuiging" van ons Westerse kultuur dat die werklikheid waarvan ons deel is, onafhanklik van ons is in dié sin dat dinge en mense in die wêreld "beperkinge/"checks'/constraints" plaas op wat ons daaroor kan sê en daarmee kan doen (210). Dit is duidelik dat binne dié beperkinge ons oortuigings en kriteria heelwat speelruimte het, en dat hulle van huis uit onvoltooid en verbeterbaar is.

Deur (tweedens) 'n beroep te doen op die werkbaarheid van kriteria en beskouinge wat ons (Westerlinge) nou het, vermy Van Niekerk die relativistiese konsekwensie dat hulle "net so goed" is soos kriteria en oortuigings wat gebied word deur onder andere bygeloof of rassisme (212). Bestaande kriteria vir wetenskap- 
like rasionaliteit stel ons in staat om suksesvol te cope; daarom behoort 'n mens volgens Van Niekerk respek te hê vir wat tot stand gebring is, en skepties te staan teenoor menings dat ons "van voor af" moet begin (213). Dit impliseer egter nie vir Van Niekerk dat kriteria en werkwyses staties is nie: die spanning tussen tradisie en vernuwing is ' $n$ kenmerk van die tussenmenslike dialoog waarin daar op voortgesette wyse gesoek word na die mees betroubare kriteria (213). In hierdie proses word sekere historiese praktyke en modi van argumentasie prysgegee om plek te maak vir beter praktyke en argumente (231). Omdat daar op hierdie wyse groei van wetenskaplike kennis, en ontwikkeling van die model van wetenskaplike rasionaliteit moontlik is, is ons historiese gelokaliseerdheid nie 'n gevangenis nie, maar ' $n$ perk wat getransendeer kan word, ' $n$ horison wat voortdurend vooruitskuif (229).

Twee kritiese opmerkings aangaande die voorgaande gedagtegang is myns insiens hier in orde. Eerstens: dit is duidelik dat die 'afgewaterde' realisme-tese van die skrywer 'n sluitstuk vorm van sy kritiek op relativisme en sy alternatief daarvoor. Hierdie tese van ' $n$ korrelasie tussen bevestigde wetenskaplike teorieë en "hoe die wêreld gesteld is" (141), word myns insiens nie voldoende beredeneer of uitgebou deur die skrywer nie. Verwysings na ' $n$ "oer-intuïsie" by die Grieke en na die "grondoortuiging van die Westerse kultuur" is in die konteks van die skrywer se hoofargumentasielyn eenvoudig nie genoeg nie.

Tweedens: die groei van wetenskaplike kennis en die ontwikkeling van die model van rasionaliteit wat deur verantwoorde wetenskapsbeoefening veronderstel moet word $(229,230)$ staan onder leiding van "waarheid as regulatiewe idee" en die "strewe na 'n soort geldigheid ... wat universeel is" $(141,143)$. Dit is waarskynlik nie onbillik teenoor die skrywer nie om te veronderstel dat "universele geldigheid" ook 'n "regulatiewe idee" is. Wat is egter die status van dié "regulatiewe ideë"? Dít is 'n belangrike vraag omdat Van Niekerk se afwysing van relativisme steun op hierdie "regulatiewe ideë". Bring sy beroep op "regulatiewe ideë" hom in die buurt van punt 3 van Nietzsche se 'Geskiedenis van 'n fout'? Is dié ideè transendentaal (dit wil sê rede-postulate) of nie? Die skrywer behandel wel dié soort vrae in sy bespreking van Habermas se beskouing, maar spel myns insiens nie sy eie standpunt voldoende uit nie.

Weens beperkte ruimte moet volstaan word met 'n blote verwysing na die belangrike punte wat Van Niekerk maak oor die praktyk as kriterium vir rasionaliteit in die menswetenskappe. Interpretasie in vele menswetenskappe het nie soseer ' $n$ tegniese interesse wat op beheersing uit is nie, maar ' $n$ "humane" of "kommunikatiewe" interesse wat daarop uit is om nuwe lewensmoontlikhede vir die hede te ontdek (216), nuwe self-verstaan vir die interpreteerder en sy gemeenskap te bemiddel (217), en die sosiaal-kulturele wêreld waarin ons leef te veran- 
der (218). Sosiale teorie het die potensiaal om self ' $\mathrm{n}$ vorm van praksis te word, en kan gemeet word aan die gevolge van dié praksis

\subsection{Rasionaliteit as legitimeringsprosedures}

Van Niekerk sluit nou aan by Paul Ricoeur se teorie van die legitimeringsproses in die mens-/sosiale wetenskappe. Dit gaan hier om 'n 'logika van validasie' van interpretasiehipoteses wat tekste en sosiale handeling as onderwerp het. Wanneer ons die sin van 'n teks, handeling of sosiale struktuur wil konstrueer, moet ons van raaiskote gebruik maak. Aangesien meerdere konflikterende interpretasies van tekste of handelinge altyd moontlik is, ontstaan daar ' $n$ "konflik van interpretasies". Dié konflik maak dit nodig om aan te toon dat 'n bepaalde interpretasie meer waarskynlik is as ' $n$ ander in die lig van wat bekend is. In hierdie prosedure word niks "dwingend bewys" of "geverifieer" nie, want die validasieproses maak gebruik van ' $n$ waarskynlikheidslogika (222). Hierdie soort prosedure het punte van ooreenstemming met juridiese prosedures waarmee ' $n$ regter of jurie besluit oor ' $n$ misdaad (dit 'as moord' of 'as manslag' interpreteer), of 'n kontrak valideer (224).

Behalwe die prosedure waarna hierbo verwys is, kan sosiale teorieë volgens Van Niekerk ook getoets word in die praktyk, insoverre as wat hulle praktyke kan transformeer. Blyk dit dat ' $n$ praktyk wat gemodelleer is aan ' $n$ bepaalde teorie die norme, waardes en voordele wat deur die teorie geformuleer word nie realiseer nie, is dit geregverdig om die praktyk "irrasioneel" te noem (225). Volgens hierdie maatstaf kan klassieke sosialistiese teorieë en die teorie van apartheid as "irrasioneel" gekwalifiseer word: sosialistiese samelewings kon nie sentrale waardes van die teorie (mededeelsaamheid, vryheid, algemene welvaart, klasseloosheid, ensovoorts) realiseer nie, terwyl dit algemene kennis is dat van aparte vryhede, menswaardigheid, ontwikkeling en self-beskikking baie min in die apartheidspraktyk tereg gekom het (226).

Hierdie onderafdeling van $R \& R$ is minder bevredigend as die res van die boek omdat dit te sketsmatig aangebied word en ernstige probleme systap. Ek verwys hier veral na Ricoeur en Hirsch se teorieë oor die 'validasie' van interpretasiehipoteses. Hirsch se opvatting dat daar nie reëls is vir die maak van goeie raaiskote nie, maar wel vir die validering van raaiskote, word onderlê deur die (positivistiese) onderskeid tussen ' $n$ 'konteks van ontdekking' en 'n 'konteks van regverdiging', en die siening dat die model van wetenskaplike rasionaliteit eintlik by die natuurwetenskappe gevind kan word. Hierdie gedagtegang gaan in teen die grein van Van Niekerk se hele betoog maar hy bly in gebreke om dit krities te bespreek. 


\section{Slot}

$R \& R$ is, samevattend, ' $n$ baie bedrewe poging om die debat oor rasionaliteit en relativisme in die menswetenskappe te rekonstueer, toe te spits en verder te voer. Hierdie toespitsing verklaar miskien die relatief min aandag wat gegee word aan die 'empiries-statistiese rede', wat tog ook 'n belangrike rol speel in die menswetenskappe.

Die skrywer se werkwyse verklaar miskien ook die relatief klein aantal praktiserende menswetenskaplikes wat in die diskussie betrek word. Van Niekerk bespreek illustratiewe gevalle om sy standpunt te stel. Hy sou egter myns insiens met vrug meer in die breedte kon gaan deur 'postmoderne' skrywers soos A.O. Hirschman (Sosiologie), S. Tyler (Antropologie), J.H. Miller (Literatuurwetenskap) en P. Kugler (Sielkunde) in sy betoog te betrek.

Die boek is, nieteenstaande die 'metavlak' waarop die argumentasie geskied, in helder en verstaanbare taal geskryf en maak in dié opsig ' $n$ indruk van lesersvriendelikheid. Die boek sou egter nog meer lesersvriendelik gewees het as dit 'n onderwerpindeks gehad het. Dit bevat egter wel 'n goeie bibliografie.

\section{Bibliografie}

BACHELARD, G. 1985. The New Scientific Spirit. Boston : Beacon Press

BERNSTEIN, R.J. 1983. Beyond Objectivism and Relativism. Oxford : Basil Blackwell Publisher Limited

DILTHEY, W. 1968. Gesammelte Schriften, Bd. 8. Stuttgart : B.G. Teubner Verlagsgesellschaft.

FEYERABEND, P. 1975. Against Method. London : Verso.

GADAMER, H-G. 1960. Wahrheit und Methode. Tübingen : J.C.B. Mohr

KUHN, T.S. 1962. The Structure of Scientific Revolutions. Chicago : University of Chicago Press.

MATTHEWS, E. 1988. Knowledge and Relativism. (In Cauchy, V., ed. Philosophy and Culture : Proceedings of the XVIIth World Congress of Philosophy, V 2. Montreal : Edition Montmorency. p. 898-901.)

NIETZSCHE, F. 1966. Werke in Drei Bänden (ed. K. Schlechta). München : Carl Hanser Verlag.

RORTY, R. 1985. Solidarity or Objectivity? (In J. Rajchman \& West, C. eds. Post-Analytic Philosophy. New York: Columbia University Press. p. 3-19.)

SCHRAG, C.O. 1989. Rationality between Modernity and Postmodernity. (In White, S.K., ed. Life-World and Politics : Between Modernity and Postmodernity. Notre Dame : University of Notre Dame Press. p. 33-45.) 